\title{
Identification Analysis of Key Performance Indicators (KPIs) at the Baptist Rural Development Model (LPPB) Using the Performance Prism
}

\author{
Trisna Murni ${ }^{1}$, Willy Abdillah ${ }^{2}$, Marta Yuli Kristianti Tambunan ${ }^{3}$ \\ Faculty of Economi and Business - Bengkulu University ${ }^{1,2,3}$ \\ \{tmurni@unib.ac.id¹,willya@unib.ac.id²,martatambunan164@gmail.com³\}
}

\begin{abstract}
This study aims to design Key Performance Indicators (KPIs) using the Performance Prism framework with a case study on a non-profit, namely the Baptist Rural Development Model. This type of research is qualitative research using case studies. The method of data is by selecting KPIs that have been collected based on empirical research, then pairwise comparisons are carried out through the Analytical Hierarchy Process questionnaire. The population in this study were LPPB stakeholders which included employees, consumers, communities, suppliers, and foundations. This KPI design produces 50 KPIs consisting of 10 stakeholder satisfaction, 10 stakeholder contributions, 10 strategies, 10 capabilities, 10 processes, from the five stakeholders which are then arranged into a Performance Measure Record Sheet. This research can provide information to other non-profits on the importance of measuring performance by translating stakeholder satisfaction and contributions as well as strategies, processes, and organizational capabilities which are facets of performance prism.
\end{abstract}

Keywords: Performance Measurement; Performance Prism; Key Performance Indicators; Performance Measurement Record Sheet; Non-Profit

\section{Introduction}

Maintaining the company's performance so that it continues to carry out its objectives on target, it is necessary to evaluate and measure the company's performance not only in terms of financial targets but also in non-financially. In an increasingly competitive environment, company management must be supported to improve its performance by perfecting the traditional performance measurement system because traditional measurement systems that emphasize financial measures as performance measures have limitations. Performance measurement has a performance measure that is reflected in Key Performance Indicators (KPI). KPI describes the measurement of several aspects of organizational performance where there are aspects that are very important to the present or future success of the organization [1]. Referring to the existing method of measuring company performance, Performance Prism (PP) emerged as a second-generation or development (especially from the balance scorecard) measurement framework designed to assist in the selection of comprehensive performance measurements that address key business issues for various organizations, profit and 
non-profit. can relate. Explicitly asking questions and critical encouragement of managers to think about relationships between measures, among ways that other measurement frameworks have not intuitively suggested [2]. This method tries to consider the stakeholders in the company, including investors, customers, suppliers, employees, and the community. The prism consists of five different facets, which should describe the complexity of actual performance measurement and management. These facets include stakeholder satisfaction, stakeholder contributions, strategies, processes, and capabilities [2]. Based on direct interviews with LPPB directors so far, LPPB performance measurement through internal evaluation among LPPB department heads at least once a month and annual evaluations related to the targets achieved regarding the development of each year, the parameters in assessing also tend to be operationally LPPB. This proves that so far LPPB is still using evaluation from the perspective of internal stakeholders, even though it is by the real function that LPPB should have to obtain measurement indicators from the perspective of society or external stakeholders as LPPB parameters in measuring performance. So, it is necessary to identify KPI to be used as parameters for measuring company performance based on the LPPB stakeholder perspective contained in the Performance Prism framework.

\section{Material and Method}

This research is qualitative. Qualitative research in the form of research with a case study approach. The main stages in the following research, among others, are in figure 1.

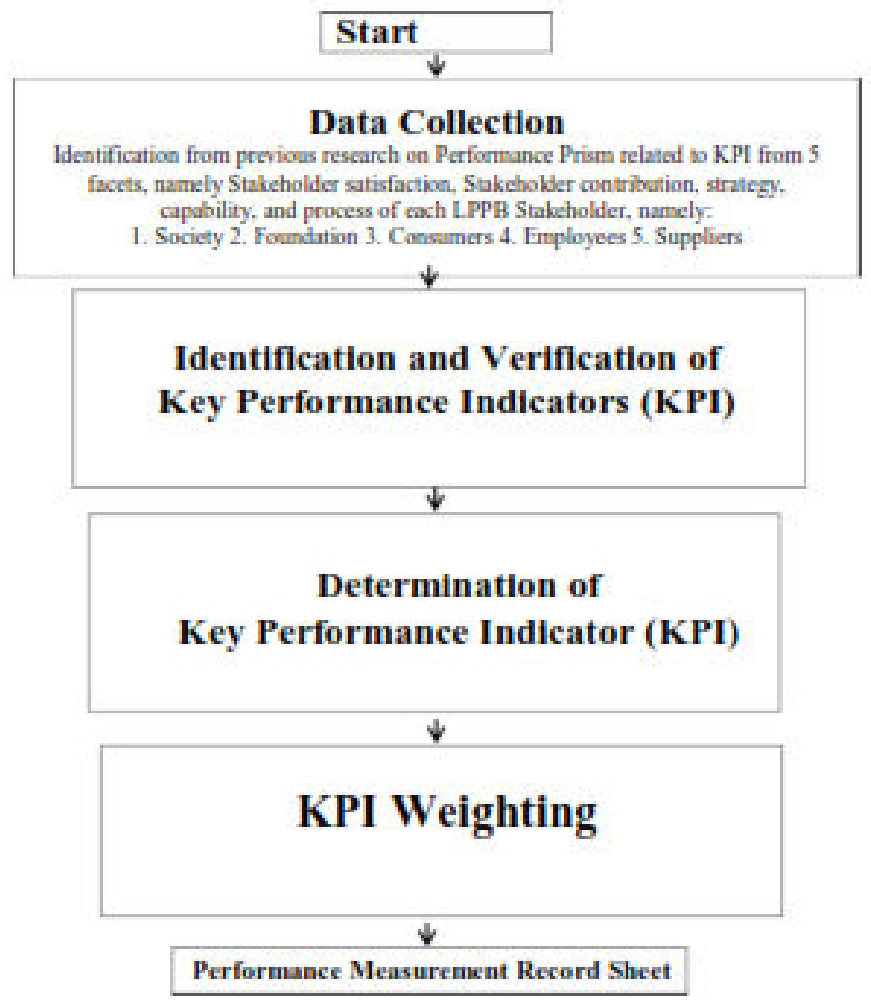

Fig. 1. Research Framework 
In this case, the identification and verification of KPIs is an effort to compare KPIs which are broadly narrowed down according to the 5 perspectives that exist in the performance prism method [3]. The target is the main stakeholders in LPPB as part of giving their ideas and opinions through the AHP questionnaire in determining the main KPIs in measuring LPPB's overall performance. The weighting of KPIs will be carried out by the LPPB's internal structural party as the part that best knows the needs and the right targets in answering the previously selected KPIs. The weight obtained will be part of the performance measurement.

\subsection{Data Collection based on Performance Prism}

This study uses qualitative research with interviews, literature searches, and identification of KPI areas from previous studies. Obtaining results through important results that exist in the PP facets, namely First, Stakeholder satisfaction - What do our key stakeholders want and need? The stakeholders considered here include consumers, employees, suppliers, owners/foundations, and the government/ community. Companies need to strive to provide satisfaction with what their stakeholders want and need and to communicate well with them so that stakeholders can carry out their roles well for the success of the company.

Second, Strategy - What strategies have we implemented to satisfy the wants and needs of our stakeholders? The definition of strategy according to Glueck and Jauch [15] is a unified, broad, and integrated plan that connects the company's strategic advantages with environmental challenges, designed to ensure that the main goals of the company can be achieved through proper implementation by the organization. Also, according to Craig \& Grant [12] strategy is the setting of long-term goals and objectives (targeting and long- term goals) of a company and the direction of action and allocation of resources needed to achieve goals and objectives (achieve the goals and objectives).

Third, Process - What critical processes need to be operationalized and improved? "The process is a series of activities starting from determining goals until the end of the target or the achievement of goals". Fourth, Resources / Capabilities - What resources do we need to operate and upgrade? Capability or ability here means the capabilities possessed by the organization including its resource expertise, business practices, technology utilization, and supporting facilities. This organizational capability is the most basic foundation that an organization must have to compete with other organizations.

Fifth, Stakeholder contributions - what contributions should we ask our stakeholders to maintain and develop this resource? Determining what to measure is the ultimate goal of measuring performance with this Performance Prism model, so the organization must consider what things are wanted and needed from its stakeholders. This is because an organization is said to have a good performance if it can convey what it wants from stakeholders which greatly affects the survival of their organization.

The results show that there are 79 KPIs that will be compared with the degree of importance through the AHP questionnaire (Table 1). Each KPI in 5 aspects of PP between stakeholders is compared to one another measuring LPPB's overall performance. The weighting of KPIs will be carried out by the LPPB's internal structural party as the part that best knows the needs and the right targets in answering the previously selected KPIs. The weight obtained will be part of the performance measurement. 
Table 1. Selection of KPI from the facets of PP

\begin{tabular}{|c|c|c|c|c|c|}
\hline Facets of PP & Foundation & Employee & Supplier & Society & Consumers \\
\hline \multirow[t]{6}{*}{$\begin{array}{l}\text { Satisfaction } \\
\text { Stakeholder }\end{array}$} & $\begin{array}{l}\text { HR can perform their } \\
\text { duties skillfully, } \\
\text { competently, and } \\
\text { achieve the desired }\end{array}$ & $\begin{array}{l}\text { Providing social and } \\
\text { health insurance } \\
\text { (Wibowo, 2017) }\end{array}$ & $\begin{array}{l}\text { Continuity of } \\
\text { good } \\
\text { cooperation } \\
\text { (Wibowo, } \\
2017 \text { ) }\end{array}$ & $\begin{array}{l}\text { Job creation } \\
\text { (Wibowo, 2017) }\end{array}$ & $\begin{array}{l}\text { Product Quality } \\
\text { [4] }\end{array}$ \\
\hline & $\begin{array}{l}\text { targets (Wibowo, } \\
\text { 2017) }\end{array}$ & $\begin{array}{l}\text { Employees teel } \\
\text { comfortable with the } \\
\text { workplace environment } \\
\text { (Kinanti \& } \\
\text { Nurhasanah, 2019) }\end{array}$ & $\begin{array}{l}\text { Increase in the } \\
\text { number of } \\
\text { purchases } \\
\text { (Wibowo, } \\
\text { 2017) }\end{array}$ & $\begin{array}{l}\text { Support for the } \\
\text { community [4] }\end{array}$ & $\begin{array}{l}\text { The accuracy of } \\
\text { serving } \\
\text { consumer } \\
\text { complaints } \\
\text { (Wibowo, 2017) }\end{array}$ \\
\hline & $\begin{array}{l}\text { Increased income } \\
\text { (Dessy, 2016) }\end{array}$ & $\begin{array}{l}\text { Compensation } \\
\text { accordingly (Dessy, } \\
2016)\end{array}$ & \multirow[t]{4}{*}{$\begin{array}{l}\text { Duration of } \\
\text { payment } \\
\text { (Wibowo, } \\
\text { 2017) }\end{array}$} & \multirow[t]{4}{*}{$\begin{array}{l}\text { Obtaining the } \\
\text { information } \\
\text { needed [4] }\end{array}$} & \multirow[t]{4}{*}{$\begin{array}{l}\text { Customer } \\
\text { satisfaction } \\
\text { (Dania, 2012) }\end{array}$} \\
\hline & $\begin{array}{l}\text { Increased visits and } \\
\text { community } \\
\text { cooperation for } \\
\text { learning/ internships } \\
\text { (Dessy,2016) }\end{array}$ & $\begin{array}{l}\text { Providing rewards for } \\
\text { achieving targets } \\
\text { (Budijanto et al., 2012) }\end{array}$ & & & \\
\hline & $\begin{array}{l}\text { Annual Reporting } \\
\text { Transparency (Kinanti } \\
\text { \& Nurhasanah, 2019) }\end{array}$ & $\begin{array}{l}\text { Clear employee } \\
\text { regulations (Budijanto } \\
\text { et al., 2012) }\end{array}$ & & & \\
\hline & $\begin{array}{l}\text { Increased production } \\
\text { capacity (Dessy, 2016) }\end{array}$ & & & & \\
\hline \multirow[t]{4}{*}{$\begin{array}{l}\text { Contribution } \\
\text { Stakeholder }\end{array}$} & $\begin{array}{l}\text { Providing } \quad \begin{array}{r}\text { increased } \\
\text { employee } \\
\text { skills } \\
\text { Kinanti }\end{array} \text { \&urhasanah, 2019) }\end{array}$ & $\begin{array}{l}\text { Employee productivity } \\
\text { (Adianto, 2014) }\end{array}$ & $\begin{array}{l}\text { On-time } \\
\text { delivery } \\
\text { (Dessy, 2016) }\end{array}$ & $\begin{array}{l}\text { Partners in } \\
\text { developing } \\
\text { Science (Bora, } \\
2015 \text { ) }\end{array}$ & $\begin{array}{l}\text { Suggestions } \\
\text { from Customers } \\
\text { (Dessy, 2016) }\end{array}$ \\
\hline & $\begin{array}{l}\text { The provision of } \\
\text { suggestions and input } \\
\text { (Wibowo, 2017) }\end{array}$ & $\begin{array}{l}\text { Employee discipline } \\
\text { (Budijanto et al., 2012) }\end{array}$ & $\begin{array}{l}\text { Quality and } \\
\text { quantity } \\
\text { accuracy } \\
\text { (Adianto, } \\
\text { 2014) }\end{array}$ & $\begin{array}{l}\text { Number and } \\
\text { quality of local } \\
\text { recruitment } \\
\text { (Wibowo, 2017) }\end{array}$ & $\begin{array}{l}\text { Customer } \\
\text { benefits get } \\
\text { (Dania, 2012) }\end{array}$ \\
\hline & $\begin{array}{l}\text { Guarantee of employee } \\
\text { welfare (Wibowo, 2017) }\end{array}$ & $\begin{array}{l}\text { Employee competence } \\
\text { (Adianto, 2014) }\end{array}$ & $\begin{array}{l}\text { Reasonable } \\
\text { prices } \\
\text { (Wibowo, } \\
\text { 2017) }\end{array}$ & $\begin{array}{l}\text { Community } \\
\text { Contribution for } \\
\text { Development } \\
\text { (Wibowo, 2017) }\end{array}$ & \\
\hline & & $\begin{array}{l}\text { Following the } \\
\text { procedure properly } \\
\text { (Dessy, 2016) }\end{array}$ & & $\begin{array}{l}\text { Percentage of } \\
\text { Permits granted } \\
\text { (Wibowo, 2017) }\end{array}$ & \\
\hline \multirow[t]{2}{*}{ Strategy } & $\begin{array}{l}\text { Creation of superior } \\
\text { products (Wibowo, } \\
2017 \text { ) }\end{array}$ & $\begin{array}{l}\text { Increased participation in } \\
\text { training (Wibowo, 2017) }\end{array}$ & $\begin{array}{l}\text { Maintain } \\
\text { communica- } \\
\text { tion (Wibowo, } \\
2017 \text { ) }\end{array}$ & $\begin{array}{l}\text { Fast company } \\
\text { response to } \\
\text { society } \\
\text { (Dessy, 2016) }\end{array}$ & $\begin{array}{l}\text { Timely } \\
\text { provision } \\
\text { (Dania, 2012) }\end{array}$ \\
\hline & Good service [5] & $\begin{array}{l}\text { Placing employees } \\
\text { according to their }\end{array}$ & $\begin{array}{l}\text { Fulfillment } \\
\text { production of }\end{array}$ & $\begin{array}{l}\text { Fulfillment of } \\
\text { the company }\end{array}$ & $\begin{array}{l}\text { Consumer } \\
\text { loyalty }\end{array}$ \\
\hline
\end{tabular}




\begin{tabular}{|c|c|c|c|c|}
\hline \multirow{3}{*}{$\begin{array}{l}\text { Increase in the } \\
\text { percentage of products } \\
\text { sold (Wibowo, 2017) }\end{array}$} & $\begin{array}{l}\text { specialties(Wibowo, } \\
\text { 2017) }\end{array}$ & $\begin{array}{l}\text { raw materials } \\
\text { (Dania, 2012) }\end{array}$ & $\begin{array}{l}\text { to the } \\
\text { environment }\end{array}$ & $\begin{array}{l}\text { (Wibowo, } \\
\text { 2017) }\end{array}$ \\
\hline & $\begin{array}{l}\text { The level of } \\
\text { procurement of } \\
\text { appropriate equipment }\end{array}$ & $\begin{array}{l}\text { Supplier } \\
\text { satisfaction [4] }\end{array}$ & $\begin{array}{l}\text { government } \\
{[6]}\end{array}$ & $\begin{array}{l}\text { Increase in } \\
\text { subscribers } \\
\text { (Prastawa, } \\
\text { 2011) }\end{array}$ \\
\hline & & $\begin{array}{l}\text { Financial } \\
\text { procedures } \\
\text { (Dania, 2012) }\end{array}$ & $\begin{array}{l}\text { The company's } \\
\text { response to } \\
\text { new } \\
\text { regulations [6] }\end{array}$ & $\begin{array}{l}\text { Product and } \\
\text { service } \\
\text { developmen } \\
\text { (Prastawa, } \\
\text { 2011) }\end{array}$ \\
\hline
\end{tabular}

\begin{tabular}{|c|c|c|c|c|c|}
\hline \multirow[t]{4}{*}{ Process } & $\begin{array}{l}\text { Increase in the number } \\
\text { of sales (Wibowo, } \\
\text { 2017) }\end{array}$ & $\begin{array}{l}\text { Providing an } \\
\text { understanding of } \mathrm{OHS} \text { to } \\
\text { employees [4] }\end{array}$ & $\begin{array}{l}\text { Quality and } \\
\text { quantity of } \\
\text { raw materials } \\
\text { (Dania, 2012) }\end{array}$ & $\begin{array}{l}\text { Use of local } \\
\text { resources [4] }\end{array}$ & $\begin{array}{l}\text { Frequency of } \\
\text { promotion and } \\
\text { product } \\
\text { introduction } \\
\text { (Prastawa, } \\
\text { 2011) }\end{array}$ \\
\hline & $\begin{array}{l}\text { Open to accept all } \\
\text { groups to share } \\
\text { information related to }\end{array}$ & $\begin{array}{l}\text { Good open } \\
\text { communication } \\
\text { between subordinates }\end{array}$ & $\begin{array}{l}\text { Making } \\
\text { quality } \\
\text { product }\end{array}$ & $\begin{array}{l}\text { Partnership } \\
\text { and } \\
\text { community }\end{array}$ & $\begin{array}{l}\text { Measurement } \\
\text { of market } \\
\text { needs and }\end{array}$ \\
\hline & $\begin{array}{l}\text { agricultural technology } \\
\text { [4] }\end{array}$ & $\begin{array}{l}\text { and superiors } \\
\text { (Wibowo,2017) }\end{array}$ & $\begin{array}{l}\text { standards } \\
\text { (Dania, 2012) }\end{array}$ & $\begin{array}{l}\text { development } \\
\text { programs [6] }\end{array}$ & $\begin{array}{l}\text { wants } \\
\text { (Wibowo, } \\
\text { 2017) }\end{array}$ \\
\hline & & $\begin{array}{l}\text { Increasing the use of } \\
\text { education funds and } \\
\text { health funds [6] } \\
\text { Coordinating the } \\
\text { procurement of } \\
\text { equipment needed [6] }\end{array}$ & & $\begin{array}{l}\text { Use of local } \\
\text { resources [4] }\end{array}$ & $\begin{array}{l}\text { Number of } \\
\text { regular } \\
\text { consumers [3] }\end{array}$ \\
\hline \multirow[t]{3}{*}{ Capability } & $\begin{array}{l}\text { Financial Control/ } \\
\text { Audit [6] }\end{array}$ & OHS Control [4] & $\begin{array}{l}\text { System } \\
\text { planning } \\
\text { (Wibowo, } \\
\text { 2017) }\end{array}$ & $\begin{array}{l}\text { Training on } \\
\text { local resources } \\
{[4]}\end{array}$ & $\begin{array}{l}\text { Customer } \\
\text { service (Dania, } \\
2012 \text { ) }\end{array}$ \\
\hline & $\begin{array}{l}\text { Completeness of } \\
\text { company data } \\
\text { information }[4]\end{array}$ & $\begin{array}{l}\text { Make clear rules and } \\
\text { regulations (SOP) [4] }\end{array}$ & $\begin{array}{l}\text { Providing } \\
\text { value/benefits } \\
\text { to suppliers [4] }\end{array}$ & $\begin{array}{l}\text { Collaboration } \\
\text { in conducting } \\
\text { research [7] }\end{array}$ & $\begin{array}{l}\text { The ability to } \\
\text { fulfill } \\
\text { customer } \\
\text { desires (Dania, } \\
2012 \text { ) }\end{array}$ \\
\hline & & $\begin{array}{l}\text { The number of resolved } \\
\text { employee complaints } \\
\text { [6] }\end{array}$ & $\begin{array}{l}\text { Accuracy of } \\
\text { payments to } \\
\text { suppliers [4] }\end{array}$ & & $\begin{array}{l}\text { Reasonable } \\
\text { prices } \\
\text { (Wibowo, } \\
2017 \text { ) }\end{array}$ \\
\hline
\end{tabular}

Source: 2020 Analysis Results

AHP is used to derive the ratio scale from several paired comparisons that are discrete or continuous. Pairwise comparisons can be obtained through actual measurements as well as relative measurements of degrees of liking, or importance or feelings. Thus this method is very useful to help obtain a ratio scale of things that were previously difficult to measure such as opinions, feelings, behaviors, and beliefs [19] Furthermore, verification is carried out by distributing questionnaires to LPPB stakeholders to obtain data and the data is processed by expert choice v11.

\subsection{Population and Sample}


The population in this study were 99 respondents consisting of 5 LPPB stakeholders (foundations, employees, suppliers, consumers, and the community). KPIs that have been identified as previously described are verified for their superiority through the AHP questionnaire by the LPPB stakeholders as the population from this sampling. The sample is part of the number and characteristics of the population [20]. The sampling method in this study using a purposive sampling method.

\begin{tabular}{cc}
\multicolumn{2}{c}{ Table 2. Research Population } \\
\hline Stakeholder & Population \\
\hline Foundation & 14 \\
Employee & 20 \\
Supplier & 5 \\
Society & 30 \\
Consumer & 30 \\
Total & 99 \\
\hline Source: 2020 Analysis Results
\end{tabular}

\section{Result and Discussion}

\subsection{Result}

The main steps that need to be taken in identifying and verifying the suitability of the needs of the 15-19 KPIs of each Stakeholder (foundations, communities, employees, suppliers, and consumers) are described based on previous research. Processing the answers to the distributed AHP questionnaire. The determination of KPI is carried out to determine performance indicators that can be used as key indicators so that performance improvements can be made faster. Hope and Fraser suggest less than 10 KPIs. The 10/80/10 rule (10 KRI or Key Result Indicator, up to $80 \mathrm{PI}$, and $10 \mathrm{KPI}$ ) is a good guide for organizations [1]. Based on this, the weighting of each Stakeholder is 15-19 KPIs, then the 10 KPIs are selected with the 2 highest weights between perspectives as KPIs (Tabel 3).

Table 3. Key Performance Indicator (KPI) of LPPB

\begin{tabular}{llcl}
\hline Stakeholder & Facets of PP & Code & \\
\hline Employee & Stakeholder & E1 & Percentage of employees feeling comfortable \\
& Satisfaction & E2 & Percentage of social and health security provision \\
& Stakeholder & E3 & Percentage of work accidents \\
& Contribution & E4 & Absence percentage \\
& Strategy & E5 & Employee specialization percentage \\
& & E6 & The appropriate level of equipment procurement \\
& Capability & E7 & Number of resolved employee complaints \\
& Erocess & E9 & Percentage of communication in internal cooperation \\
& & E10 & Coordinating the procurement of required equipment \\
\hline \hline Consumer & Stakeholder & C1 & Product quality percentage \\
& Satisfaction & C2 & Percentage of Customer Satisfaction \\
& Stakeholder & C3 & Customer benefits get
\end{tabular}




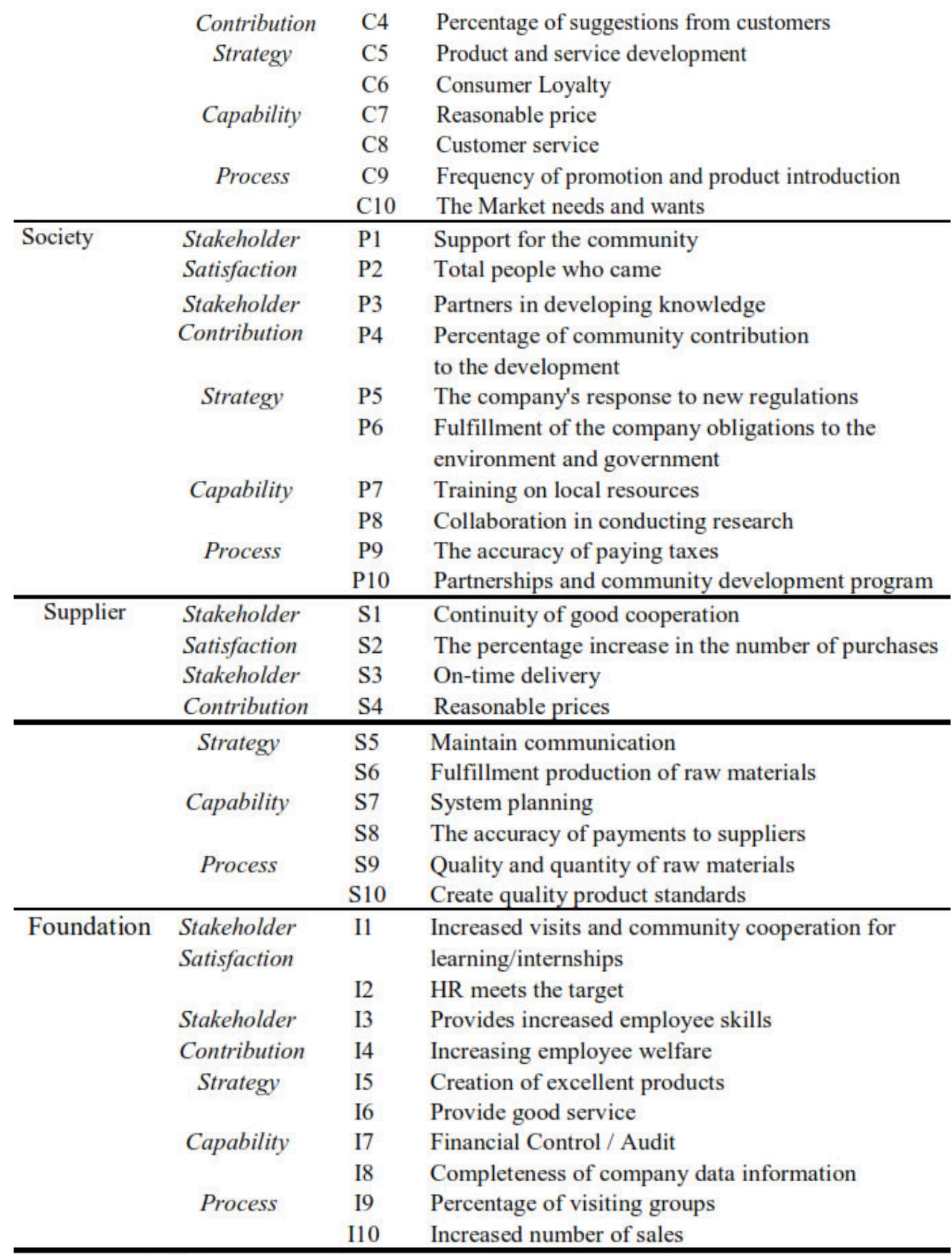

Source: 2020 Analysis Results

The KPI parameters that have been formulated by the LPPB stakeholders as above are then entered in the AHP questionnaire to be weighted according to LPPB needs. Weights function in determining the level of importance of KPIs to business success, these weights can be used to 
determine the difference between the desired prerequisites and the environmental conditions of the company [11]. The weight for each category will be filled by the most qualified LPPB structural officials as the part that has the most impact on the LPPB running decision, namely the LPPB director, head of the office, personnel \& public relations, head of operations, and head of training \& counseling.

Performance parameters based on table 4 with the highest weight are (C1). The percentage of product quality with a weight of 0.075 is part of the consumer stakeholders, while the lowest weight is (S2). The percentage increase in the number of purchases with a weight of 0.001 is part of the supplier stakeholders. The highest weight of each stakeholder, namely from the highest employee (E4) Percentage of attendance with a weight of 0.051 , from the highest consumer (C1) Percentage of product quality with a weight of 0.075 , from the highest community (P1) Support to society with weight 0.026 , from the highest supplier (S8) Accuracy of payment to suppliers with a weight of 0.053 , and from the highest foundation (I7) Financial Control / Audit with a weight 0.020 with the hope that these five KPIs will be in an excellent performance to be able to increase the performance value of the LPPB for the better.

Tabel 4. The Weight of each KPI

\begin{tabular}{llllllllll}
\hline KPI & Weight & KPI & Weight & KPI & Weight & KPI & Weight & KPI & Weight \\
\hline E1 & 0.016 & C1 & 0.075 & P1 & 0.026 & S1 & 0.008 & I1 & 0.003 \\
E2 & 0.014 & C2 & 0.033 & P2 & 0.017 & S2 & 0.001 & I2 & 0.004 \\
E3 & 0.029 & C3 & 0.030 & P3 & 0.006 & S3 & 0.030 & I3 & 0.010 \\
E4 & 0.051 & C4 & 0.026 & P4 & 0.011 & S4 & 0.015 & I4 & 0.010 \\
E5 & 0.033 & C5 & 0.031 & P5 & 0.005 & S5 & 0.015 & I5 & 0.009 \\
E6 & 0.018 & C6 & 0.007 & P6 & 0.008 & S6 & 0.015 & I6 & 0.012 \\
E7 & 0.046 & C7 & 0.025 & P7 & 0.016 & S7 & 0.022 & I7 & 0.020 \\
E8 & 0.037 & C8 & 0.039 & P8 & 0.018 & S8 & 0.053 & I8 & 0.007 \\
E9 & 0.023 & C9 & 0.020 & P9 & 0.009 & S9 & 0.011 & I9 & 0.015 \\
E10 & 0.004 & C10 & 0.036 & P10 & 0.008 & S10 & 0.017 & I10 & 0.005 \\
\hline \multicolumn{7}{c}{ Source: 2020} & Analysis
\end{tabular}

Source: 2020 Analysis Results

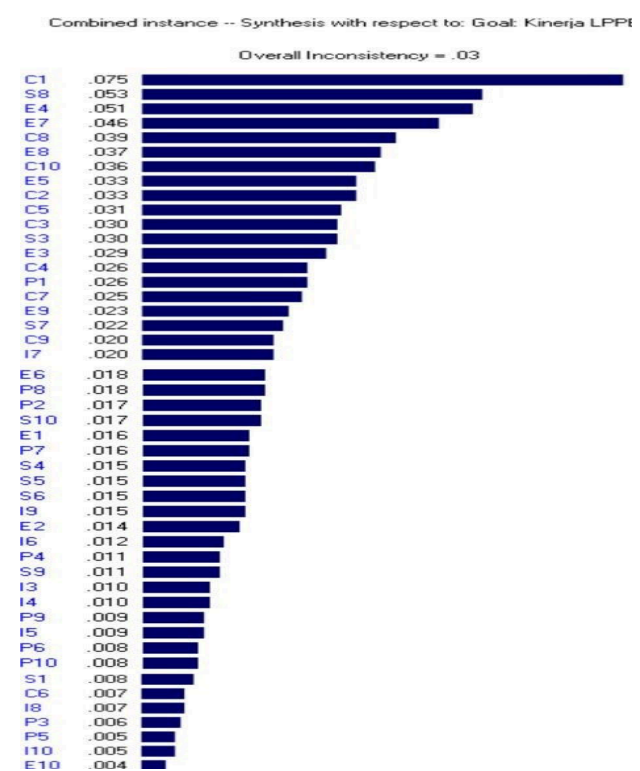

Fig. 2. The results of the KPI weighting with expert choice v11 
By the research [9] stated that the performance measurement record sheet consists of 10 important elements in its framework. The elements that can be generalized in measurements in LPPB are, The frequency elements are flattened for all indicators so that they are carried out in one period, namely the calculation for a year. The element of the party that will measure is the head of the office as the administrative responsible for the LPPB to be able to report the results of the data used as a measure in seeing the productivity of the LPPB's performance in its periodic years. Elements that will act on the data include structural parties from the LPPB as parties who will seek solutions and development processes needed by LPPB in the future. The target elements and what elements they will do then are left directly to the LPPB who best knows the degree of need and optimization in their operations towards good performance

Table 5. Performance Measurement Record Sheet LPPB

\begin{tabular}{|c|c|c|c|c|c|c|}
\hline Code & KPI & $\begin{array}{l}\text { Opti } \\
\text { mal }\end{array}$ & $\begin{array}{l}\text { Mi } \\
\text { nim } \\
\text { al }\end{array}$ & $\begin{array}{c}\text { Year } \\
\text { of } \\
\text { Com Target } \\
\text { paris } \\
\text { on } \\
\end{array}$ & Real & Weight \\
\hline El & $\begin{array}{l}\text { Percentage of employees feeling } \\
\text { comfortable }\end{array}$ & & & & & 0.016 \\
\hline E2 & $\begin{array}{l}\text { Percentage of social and health security } \\
\text { provision }\end{array}$ & & & & & 0.014 \\
\hline $\mathrm{E3}$ & Percentage of work accidents & & & & & 0.029 \\
\hline E4 & Absence percentage & & & & & 0.051 \\
\hline E5 & Employee specialization percentage & & & & & 0.033 \\
\hline E6 6 & $\begin{array}{l}\text { The appropriate level of equipment } \\
\text { procurement }\end{array}$ & & & & & 0.018 \\
\hline E7 & Number of resolved employee complaints & & & & & 0.046 \\
\hline E8 & Clear rules and regulations (SOP). & & & & & 0.037 \\
\hline E9 & $\begin{array}{l}\text { Percentage of communication in internal } \\
\text { cogperation }\end{array}$ & & & & & 0.023 \\
\hline E10 & $\begin{array}{l}\text { Coordinating the procurement of required } \\
\text { equipment }\end{array}$ & & & & & 0.004 \\
\hline $\mathrm{Cl}$ & Product quality percentage & & & & & 0.075 \\
\hline $\mathrm{C} 2$ & Percentage of Customer Satisfaction & & & & & 0.033 \\
\hline $\mathrm{C} 3$ & Custamer benefits get & & & & & 0.030 \\
\hline $\mathrm{C} 4$ & Percentage of suggestions from customers & & & & & 0.026 \\
\hline $\mathrm{C5}$ & Product and service development & & & & & 0.031 \\
\hline $\mathrm{C} 6$ & Consumer Loyality & & & & & 0.007 \\
\hline $\mathrm{C7}$ & Reasonable prices & & & & & 0.025 \\
\hline $\mathrm{Cs}$ & Custamer service & & & & & 0.039 \\
\hline $\mathrm{Cg}$ & $\begin{array}{l}\text { Frequency of promotion and product } \\
\text { introduction }\end{array}$ & & & & & 0.020 \\
\hline $\mathrm{C} 10$ & The Market needs and wants & & & & & 0.036 \\
\hline P1 & Support for the community & & & & & 0.026 \\
\hline
\end{tabular}




\begin{tabular}{|c|c|c|}
\hline $\mathrm{P} 2$ & The people who came & 0.017 \\
\hline P3 & Purtners in developing knowlodge & 0.006 \\
\hline P4 & $\begin{array}{l}\text { Percentage of community contribution to } \\
\text { the development }\end{array}$ & 0.011 \\
\hline $\mathrm{p5}$ & $\begin{array}{l}\text { The company's response to new } \\
\text { regulations }\end{array}$ & 0.005 \\
\hline $\mathrm{P} 6$ & $\begin{array}{l}\text { Fulfillment of the company obligations iv } \\
\text { the environment and govemment }\end{array}$ & 0.008 \\
\hline p7 & Training on local resources & 0.016 \\
\hline P8 & Collaboration in conducting research & 0.018 \\
\hline p9 & The accuracy of paying taxes & 0.009 \\
\hline$\overline{\text { P10 }}$ & $\begin{array}{l}\text { Partuerships and community development } \\
\text { program }\end{array}$ & 0.008 \\
\hline 51 & Continuity of good cooperation & 0.008 \\
\hline$\$ 2$ & $\begin{array}{l}\text { The persentage increase in the number of } \\
\text { purchases }\end{array}$ & 0.001 \\
\hline 53 & On-lime delivary & 0.030 \\
\hline 54 & Reasonable prices & 0.015 \\
\hline 55 & Maintain communication & 0.015 \\
\hline 56 & Fulfillment prodaction of raw materials & 0.015 \\
\hline 57 & System planning & 0.022 \\
\hline 58 & The accuracy of payments to suppliers & 0.053 \\
\hline 59 & Quality and quantity of raw materials & 0.011 \\
\hline$\$ 10$ & Create quality product standards & 0.017 \\
\hline$\overline{I I}$ & $\begin{array}{l}\text { Increased visits and community } \\
\text { cooperation for leaming intemships }\end{array}$ & 0.003 \\
\hline 12 & HR mets the target & 0.004 \\
\hline 13 & Provides increased employee skills & 0.010 \\
\hline 14 & Increasing employee welfare & 0.010 \\
\hline 15 & Creation of excellent products & 0.009 \\
\hline 16 & Provide good service & 0.012 \\
\hline 17 & Fimancial Control / Audit & 0.020 \\
\hline 18 & $\begin{array}{l}\text { Completeness of company daha } \\
\text { information }\end{array}$ & 0.007 \\
\hline 19 & Percentage of visiting groups & 0.015 \\
\hline 110 & Increased number of sales & 0.005 \\
\hline
\end{tabular}

Source: 2020 Analysis Results 


\subsection{Discussion}

According to Neely \& Adams (2003), if a company fails to provide added value to its stakeholders, it can result in a reduction in the company's reputation, but if stakeholder satisfaction is met, it means that the company's performance is good. Performance Prism does not only talk about what the stakeholders need and want but also the feedback for what LPPB needs and wants from stakeholders. Therefore, it is necessary to identify the contribution of each stakeholder to develop LPPB capability.

The identification results show that there is 10 stakeholder satisfaction from each stakeholder that must be fulfilled by LPPB which can be seen in table 3. Each stakeholder generates 2 KPIs such as employees (E1, E2), consumers (C1, C2), communities (P1, P2), suppliers (S1, S2), and foundations (I1, I2). As stated in the table, the KPI is also used in 5 empirical studies as a reference part in their management, including 1 KPI from Kinanti and Nurhasanah's research (2019), 1 KPI from Dania's research (2012), 1 KPI from Dessy's research (2016), 3 KPIs from Adianto's research (2014), and 4 KPIs from Wibowo's research (2017).

The results of the identification of the 10 KPIs that are expected by LPPB from their stakeholders can be seen in table 3. Each stakeholder produces 2 KPIs such as employees (E3, E4), consumers (C3, C4), communities (P3, P4), suppliers (S3, S4), and foundations (I3, I4). As stated in table 3, the KPI is also used in 6 empirical studies as a reference part in the management of KPI selection, including 1 KPI from the research of Budijanto et al., (2012), 1 KPI from Dania's research (2012), 1 KPI from Bora's research (2015), 1 KPI from Kinanti and Nurhasanah's research (2019), 3 KPIs from Dessy's research (2016), and 3 KPIs from Wibowo's research (2017)

Next is the strategy identification process, strategy formulation is needed to measure organizational performance because it can be used as a monitor, the extent to which organizational goals have been achieved so that management can take quick and appropriate steps in making decisions to improve company performance. The strategy identification results show that 10 strategies must be implemented by LPPB.

The results of the identification of strategies resulted in 10 KPIs that must be carried out by LPPB to obtain good performance, can be seen in table 3. Where each stakeholder produces 2 KPIs such as employees (E5, E6), consumers (C5, C6), community (P5, P6), suppliers (S5, S6), and foundations $(\mathrm{I} 5, \mathrm{I} 6)$. As stated in the table, the KPI is also used in 5 empirical studies as a reference part in the management of KPI selection, including 1 KPI from Prastawa's research (2011), 1 KPI from Dania's research (2012), 1 KPI from Kinanti and Nurhasanah's research. (2019), 3 KPIs from Dessy's research (2016), and 4 KPIs from Wibowo's research (2017). Then, process identification according to Neely et al., (2002) is how the company can carry out the strategy. A good process must support the achievement of strategy, thus enabling the company to have high performance. The results of the process identification show that 10 processes support the implementation of the strategy.

The results of the identification process resulted in 10 KPIs that must be carried out by LPPB to obtain good performance, which can be seen in table 3 . Where each stakeholder produces 2 KPIs such as employees (E9, E10), consumers (C9, C10), communities (P9, P10), suppliers (S9, $\mathrm{S} 10)$, and foundations $(\mathrm{I} 9, \mathrm{I} 10)$. As stated in the table, this KPI is also used in 6 empirical studies as a reference part in the management of KPI selection, including 1 KPI from Prastawa's research (2011), 1 KPI fro $m$ the research of Budijanto et al. (2012), 1 KPI from Adianto's research (2014), 2 KPIs from Dessy's research (2016), 2 KPIs from Dania's research (2012), and 3 KPIs from Wibowo's research (2017). 
Identification of capabilities in seeing the capabilities that are owned and need to be improved. Capability is the ability of the company, whether human resources, business processes, physical infrastructure, tools or machines, and supporting facilities. Capability is very important in the organization because it can describe the organization's ability to meet the wishes of the stakeholders. Identification of capabilities that need to be measured by

LPPB, which amounts to 10 capabilitie. The results of capability identification produced 10 KPIs that must be carried out by LPPB to obtain good performance can be seen in table 3 . Each stakeholder produces 2 KPIs such as employees (E7, E8), consumers (C7, C8), community (P7, P8), suppliers. (S7, S8), and foundations (I7, I8). As stated in the table, this KPI is also used in 5 empirical studies as a reference part in the management of KPI selection, including 1 KPI from Dania's research (2012), 1 KPI from Bora's research (2015), 2 KPI from Dessy's research (2016) ), 2 KPIs from Wibowo's research (2017), and 4 KPIs from Adianto's research (2014).

After the KPIs were identified through weighting between KPIs carried out by 5 respondents who were the LPPB structural members who best understood the LPPB needs. In fulfilling the next step in completing the main results that will become the core of measurement, namely the establishment of a performance measurement record sheet. A performance measure log sheet is used to determine what constitutes a "good" measure of performance. It also relates to a framework that ensures that actions are clearly defined and based on formulas and explicitly defined sources of data. The performance measurement record sheet consists of a table containing the $50 \mathrm{KPIs}$ consisting of the optimal value, the pessimistic value, the comparison year, the weight, and the realization in the current measurement year which will later be used in measuring LPPB performance.

\section{Conclusion}

First, the KPIs generated through the Performance Prism method consist of 50 KPIs selected from 79 KPIs collected based on empirical research. The performance prism method with 5 perspectives generates (10 KPI Stakeholder satisfaction, 10 KPI stakeholder contributions, 10 KPI strategy, 10 KPI capability, and 10 KPI process) from 5 LPPB stakeholders (employees, consumers, communities, suppliers, foundations) through multiple selections between The main KPI by each stakeholder uses the AHP questionnaire with a total of 99 respondents.

Second, the weighting of $50 \mathrm{KPIs}$ is carried out by the LPPB structural party in terms of selecting priority KPIs whose results are considered the most important in maximizing later performance measurements. The results of the highest weight of the KPI are at $(\mathrm{C} 1)$. The percentage of product quality is part of the consumer stakeholders, while the lowest weight is (S2). The percentage of the increase in the number of purchases is part of the supplier stakeholders. The highest weight of each stakeholder, namely from the highest employee (E4) Percentage of absenteeism, from the highest consumer (C1) Percentage of product quality, from the highest community (P1) Support to the community, from the highest supplier (S8), Accuracy of payments to suppliers, and from the highest level of foundations (I7) Financial / Audit control with the hope that these five KPIs will be in an excellent performance to be able to increase the LPPB's performance value for the better.

Third, the 50 KPIs have formed a performance measurement record sheet which explained in detail the 10 important elements in measuring performance. The ten elements include the title size, objectives, linkages, targets, formulas, frequency, who is measuring, the source of the data, who act on the data, what they do. 


\section{References}

[1] D. Parmenter, Key Performance Indicators ( KPI ). 2010.

[2] A. Neely and C. Adams, "Perspectives on performance: the performance prism," Cranf. Sch. Manag., 2001.

[3] M. Budijanto, Y. Priyandari, and S. E. Sari, "Perancangan Key Performance Indicators ( KPI) Menggunakan Metode Performance Prism ( Studi Kasus di Batik Putra Bengawan ), vol. 11, no. 2, pp. 153-158, 2012.

[4] Adianto, "Analisis Pengukuran Kinerja Perusahaan dengan Metode Performance Prism dan Scoring Objective Matrix (OMAX) pada PT. BPAS," Anal. Pengukuran Kinerja Perusah. Dengan Metod. Perform. Prism Dan Scoring Object. Matrix Pada Pt. Bpas, vol. 18 , pp. $61-70,2014$.

[5] W. A. Kinanti and N. Nurhasanah, "Usulan Perancangan Key Performance Indicator (KPI) dengan Konsep Green HRM menggunakan Perspektif Performance Prism dan Metode AHP pada Waris Cafe," J. Al-AZHAR Indones. SERI SAINS DAN Teknol., vol. 5, no. 2, p. 70, 2019, doi: 10.36722/sst.v5i2.353.

[6] M. Dessy, "Desain Pengukuran Kinerja Perusahaan dengan Metode Performance Prism dan objective Matrix di PT . Wijaya Karya Beton PPB Sumut," 2016.

[7] M. A. Bora, "Desain Pengukuran Kinerja Jasa Pendidikan dengan Metode Performance Prism (Studi Kasus pada Perguruan Tinggi STT Ibnu Sina Batam),” vol. 10, no. April, pp. 1-118, 2015.

[8] T. L. Saaty, "Decision making with the Analytic Hierarchy Process," Sci. Iran., 2002, DOI: 10.1504/ijssci.2008.017590.

[9] A. Neely, H. Richards, J. Mills, and K. Platts, "Designing performance measures : a structured approach," vol. 17, no. 11, pp. 1131-1152, 1997.

[10] A. Neely and C. Adams, "The Performance Prism in Action - a Case Study," Control, 2003.

[11] Arianto EZ, and Pratiwi SG, "Analisa Pengukuran Kinerja dengan Metode Performance Prism (Studi Kasus PT. Petrokimia Gresik),” 2010, <digilib.its.ac.id/public/ITSUndergraduate-11028-Pa-per.pdf $>$.

[12] Craig, J.C., and R.M. Grant, "Strategic Management. The Fast-Track MBA Series," Penerbit Elex Media Computindo, Jakarta, 1996.

[13] Dania, et al, "Analisis pengukuran kinerja korporasi menggunakan metode Performance Prism. Jurnal Teknologi Pertanian,” 13(1), 67-77, 2012.

[14] Dorf, R. C., Raitanen, M, "The Balanced Scorecard: Translating Strategy Into Action,'IEEE.Vol.85 No.9.

[15] Glueck, William F dan Lawrence R. Jauch. (1989). Manajemen Strategis dan Kebijakan Perusahaan. Jakarta: Erlangga, 1997.

[16] Moeheriono. Perencanaan, Aplikasi, dan Pengembangan Indikator Kinerja Utama (IKU) Bisnis dan Publik.Jakarta:Rajawali Pers, 2012.

[17] Prastawa, Heru \& Agung, S. Sistem Pengukuran Kinerja dengan Metode Performance Prism (Studi Kasus kepada Rumah Sakit Islam Sultan Agung Semarang). Teknik, 32(1), 25-33. 2012, https://doi.org/10.14710/teknik.v32i1.1684

[18] Rivai, Veithzal, et al, "Performance Appraisal Edisi Kedua," Jakarta: Rajawali Pers, 2008.

[19] Saaty, T. L. "Decision making with the Analytic Hierarchy Process. Scientia Iranica," 
2002, https://doi.org/10.1504/ijssci.2008.017590

[20] Sugiyono, "Metode Penelitian Kuantitatif Kualitatif dan R \& D," Bandung: Alfabeta, (2012). [21] Wibowo, Sugeng Priyo," Usulan Perbaikan Kinerja Perusahaan (KPI) dengan Menggunakan Metode Performance Prism dan Metode OMAX di PT Globalindo Intimates Klaten Jawa Tengah,“ Yogyakarta, 2017. 